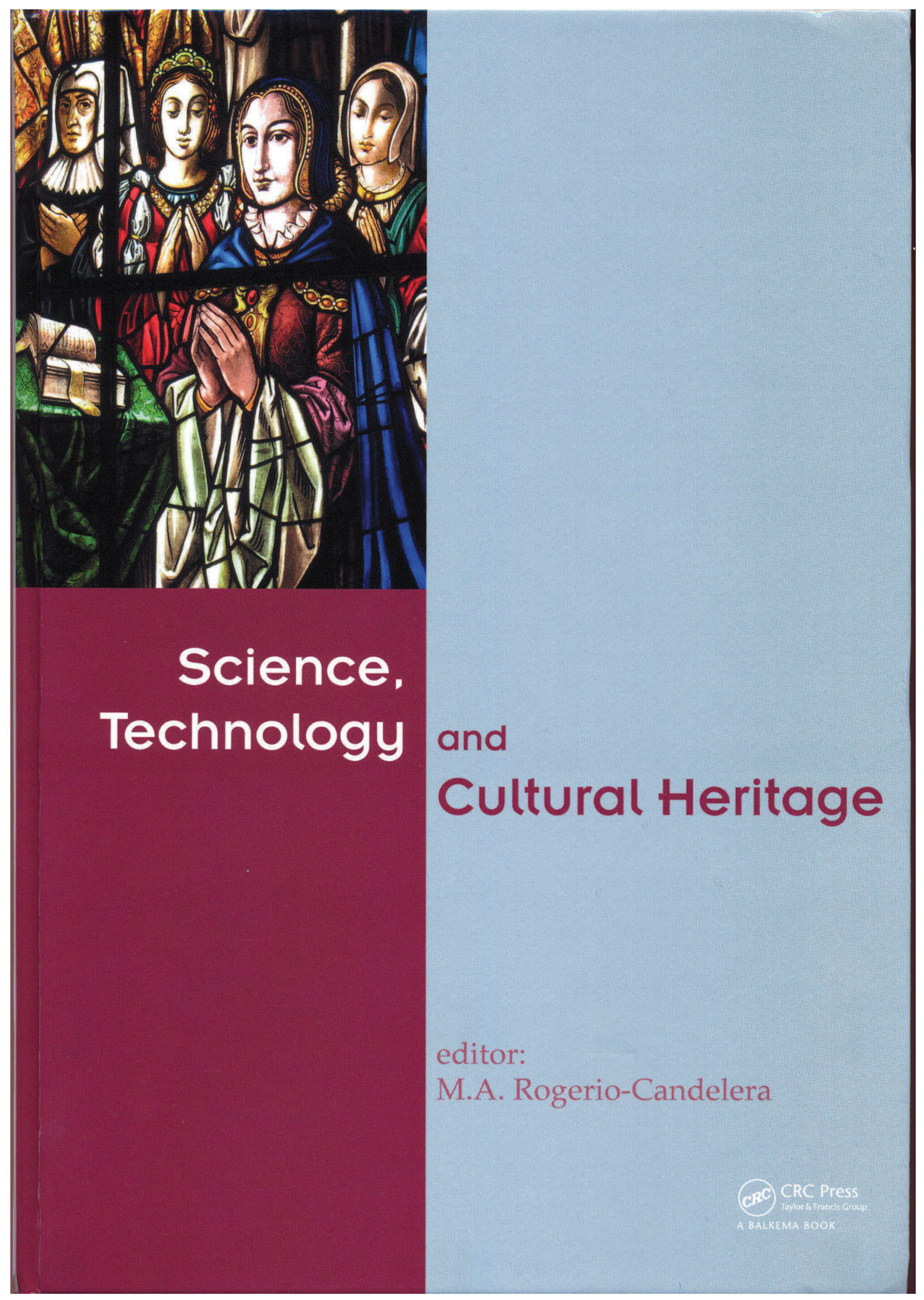


CRC Press/Balkema is an imprint of the Taylor \& Francis Group, an informa business

\section{(C) 2014 Taylor \& Francis Group, London, UK}

Typeset by V Publishing Solutions Pvt Ltd., Chennai, India Printed and bound in Great Britain by CPI Group (UK) Ltd, Croydon, CR0 4YY

All rights reserved. No part of this publication or the information contained herein may be reproduced, stored in a retrieval system, or transmitted in any form or by any means, electronic, mechanical, by photocopying, recording or otherwise, without written prior permission from the publisher.

Although all care is taken to ensure integrity and the quality of this publication and the information herein, no responsibility is assumed by the publishers nor the author for any damage to the property or persons as a result of operation or use of this publication and/or the information contained herein.

\section{Published by: CRC Press/Balkema}

P.O. Box 11320, 2301 EH Leiden, The Netherlands

e-mail: Pub.NL@taylorandfrancis.com

www.crcpress.com - www.taylorandfrancis.com

ISBN: 978-1-138-02744-2 (Hbk)

ISBN: 978-1-315-71242-0 (eBook PDF) 


\title{
Characterisation and purification of proteic binders used in easel paintings
}

\author{
A. Branco \& A. Fialho \\ Chemistry Department and HERCULES Laboratory, University of Evora, Evora, Portugal
}

C. Salvador, A. Candeias \& A.T. Caldeira

Chemistry Department, Chemistry Centre of Evora and HERCULES Laboratory,

University of Evora, Evora, Portugal

M.F. Candeias

Chemistry Department and Institute of Mediterranean Agricultural and Environmental Sciences (ICAAM), University of Evora, Evora, Portugal

S. Martins, M. Semedo \& A. Karmali

Chemical Engineering and Biotechnology Research Center and Departmental Area of Chemical Engineering, High Institute of Engineering of Lisbon, Lisbon, Portugal

ABSTRACT: In paintings the characterization of proteic binders is of great interest, since it is an important source of information for conservation and restoration practices. Some studies suggest that the organic materials used in this type of art work has been widely applied as adhesives and binders in coating layers of paintings. The proteinaceous materials such as animal glues require a special attention given the suffering degradation over time, influenced by physical, chemical and biological factors. The aim of this work is the characterisation and purification of two animal glues (rabbit fur and fish) that are commonly used as binders in easel paintings. The animal glues revealed a polysaccharide content and trace of lipids, being mainly constituted by a mix of proteins. The use of native-PAGE, spectroscopy and chromatographic techniques allowed the characterisation and purification of the proteic binders, promoting a better knowledge about this type of animal adhesives used in easel paintings.

\section{INTRODUCTION}

Historically, proteinaceous materials have frequently been used in "tempera" painting technique as paint binders (Duce 2012). Over the years a range of materials has been used as binders or adhesives, egg (albumin and ovalbumin), milk (casein), animal glues, oils, plants resins, among others, due to their ability to form adherent and elastic films of high durability (Stuart 2007, Vagnini 2008). The organic materials are used in order to reduce the porosity and water permeability, providing a better adherence to the screen, facilitate the design and application of the paint and improve the aesthetic quality of the finished product (Andreotti 2006, Ciferri 1999). It has been widely documented that organic materials in paintings undergo physical, chemical and biological modifications, as a result of the interaction with light and oxygen (Duce 2012). Some microorganisms also use for their growth organic molecules present in paintings like polysaccharides, sugar, proteins, among others (Ciferri 1999).

In paintings, the correct identification of materials used by artists as well as the characterisation of proteic binders is highly important since it holds essential information for both reconstruction and conservation techniques (Checa-Moreno 2008, Gambino 2013).

In this work, we proceed to the characterisation and purification of two animal glues, rabbit fur and fish. We used spectroscopy techniques like Fourier Transform infrared with Attenuated 